\title{
Erratum to: The dynamics of alternative male mating tactics in a population of Black Grouse Tetrao tetrix in the Italian Alps
}

\author{
D. E. Chamberlain $\cdot$ M. Bocca $\cdot$ L. Migliore $\cdot$
}

E. Caprio - A. Rolando

Published online: 21 March 2013

(C) Dt. Ornithologen-Gesellschaft e.V. 2013

Erratum to: J Ornithol (2012) 153:999-1009

DOI 10.1007/s10336-012-0821-7

Unfortunately, there was an error in reporting the location and geographic co-ordinates of the study site, Mont Avic Natural Park, under the "Study site" subheading, in the "Methods" section of the original publication. The correct location and co-ordinates should read:

Chalamy Valley, Valle $\mathrm{d}^{\prime}$ Aosta, $4^{\circ} 40^{\prime} \mathrm{N}, 7^{\circ} 35^{\prime} \mathrm{E}$.

The online version of the original article can be found under doi:10.1007/s10336-012-0821-7.

D. E. Chamberlain $(\bowtie) \cdot$ L. Migliore · E. Caprio · A. Rolando

Dipartimento di Biologia Animale e dell'Uomo,

Università di Torino, Via Accademia Albertina 13,

10123 Torino, Italy

e-mail: dan.chamberlain99@gmail.com

M. Bocca

Parco Naturale Mont Avic, Località Fabbrica 164,

11020 Champdepraz, Valle d'Aosta, Italy 